\title{
MODLITWA WEDŁUG MARKA EREMITY
}

„Nieustannie się módlcie!” (1Tes 5, 17): wezwanie św. Pawła miało ogromny wpływ na wschodnie środowisko monastyczne pierwszych wieków. Od czasów pustyni egipskiej i pierwszych form życia zakonnego istniało fundamentalne pytanie: W jaki sposób modlić się nieustannie? Otóż, wykraczając poza koncepcję modlitwy właściwej wybranym momentom dnia, modlitwa nieustanna powinna była wypełniać całe życie mnicha. Pewien apoftegmat dobrze ilustruje tę koncepcję:

„-- Jak można modlić się bezustannie (Łk 18, 1)? Ciało bowiem słabnie w czasie liturgii.

- Modlitwą nie nazywa się tylko trwać w określonym czasie modlitwy, ale zawsze". ${ }^{1}$

-,,Jaką miarę należy zachować na modlitwie?

- Miara nie została dana. Słowa «modlić się zawsze i nieustannie» (1Tes 5,17$)$ nie zawierają miary. Jeśli bowiem mnich trwa na modlitwie jedynie w chwilach wyznaczonych, to nie modli się w ogóle". ${ }^{2}$

Marek Eremita, w pełni zakorzeniony we wschodnim środowisku monastycznym, ${ }^{3}$ również zwraca uwagę na zagadnienie nieustannej modlitwy, które zajmuje wręcz całość jego dzieł. Trzeba jednak powiedzieć od razu, że Marek Eremita nie jest wielkim teoretykiem modlitwy! Wręcz niewiele nam mówi o jej aspekcie praktycznym: nie robi żadnych odniesień do liturgii, do psalmodii, nie podaje żadnej

1 M. S t a r ow i e y s k i (tłum.), Apoftegmaty Ojców Pustyni. Jak należy przebywać w celi i o kontemplacji, 18, ŹMon 56, Kraków 2011, s. 212.

2 Tamize, 22, s. 212n.

3 Te dane biograficzne pozostają jeszcze niepewne dla badaczy. 
konkretnej „porady” dotyczącej modlitwy, żadnego odniesienia do gestów modlitewnych itp., co jest dość zaskakujące dla czytelnika nawykłego do lektury pism monastycznych i ascetycznych pierwszych wieków. Jednocześnie Marek Eremita przywiązuje ogromną wagę do nieustannej modlitwy: wszystkie jego teksty wspominają o niej! Nie mówi jednak o niej jako doradca, mający gotową do zostosowania metodę, ani jako dogmatyk, ani tym bardziej jako liturgista - ten mąż modlitwy czyni z niej bowiem „matkę cnót”: modlitwa jest wszędzie. Jednakże Marek Eremita, dystansując się od systemów i „rytuałów” modlitwy, sprzeciwia się zręcznie messalianom, którzy czynią z nieustannej modlitwy metodę na otrzymanie Ducha Świętego i sposób na zbawienie.

Marek Eremita, wierząc w napełnienie Duchem Świętym od chwili chrztu, woli podkreślać modlitwę przeżywaną w głębi serca w ramach relacji miłości między Bogiem a człowiekiem. Będąc daleki od odrzucenia modlitwy lub przywiązywania do niej mniejszej wagi niż messalianie, Marek Eremita uznaje ją za niezbędną pod każdym względem, wyliczając wszystkie jej nakazy. Jednakże umieszcza modlitwę w naszym wnętrzu, w czujności niezbędnej rozumowi do ochrony serca, które trzeba chronić dlatego, że szatan, nie zamieszkując serca (chociaż tak twierdzą messalianie), stara się do niego wejść i usunąć z niego Boga.

\section{Serce i modlitwa}

Marek Eremita staje przed pytaniem o to, jak w obliczu messalianizmu mówić o modlitwie, a zwłaszcza o wezwaniu św. Pawła do modlitwy nieustannej (1Tes 5, 17). Ta „wewnętrzna skłonność do monastycyzmu syryjskiego", ${ }^{4}$ jak zauważa Philippe Escolan, broni idei „możliwości osiągnięcia zbawienia przez metodę ascetyczną gwarantującą powodzenie". ${ }^{5}$ Główną tezą messalian jest obecność

$4 \quad \mathrm{Ph}$. E s c ol a n, Monachisme et Église. Le monachisme syrien du IVe au VIIe siècle: un monachisme charismatique, Beauchesne, Paris 1999, s. 91.

5 Tamże, s. 94. 
szatana w sercu człowieka upadłego, i to od momentu narodzin: szatan jest głęboko złączony z sercem człowieka. Metodą pozwalającą wyzwolić się od niego jest dla messalian asceza, a zwłaszcza praktyka nieustannej modlitwy ${ }^{6}$ o zajęcie przez Ducha Świętego miejsca szatana w sercu człowieka. Ani sakrament chrztu, ani pozostałe sakramenty nie mogą tego dokonać; według messalian jedynie ciągła modlitwa - uniemożliwiająca jakąkolwiek inną aktywność, taką jak np. praca - umożliwia oczyszczenie.

Tymczasem dla Marka Eremity chrzest daje całkowite oczyszczenie przez idealne napełnienie Trójcą Świętą serca ludzkiego, a temat „synergii” z Duchem jest obecny we wszystkich dziełach tego teologa i tym samym ich związek z tradycją makariańską jest bardzo silny.

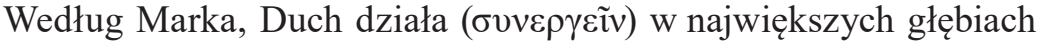
ludzkiego serca od momentu chrztu, a modlitwa jest właśnie znakiem Jego obecności w sercu wierzącego, zatem w żadnym wypadku nie wprowadza ona Ducha Świętego, jak uważają messalianie. Jednakże Marek Eremita nie odrzuca jednak modlitwy nieustannej! Według niego bowiem, jak i duchowości Wschodu, trzeba chronić serce przed prawdziwą wewnętrzną wojną, ${ }^{7}$ ponieważ szatan stara się przez zewnętrzne podpowiadanie złych myśli wniknąć do świętego domu serca, gdzie mieszka Trójca. ,Jedynym celem diabła, jak pisze Marek Eremita, jest oddalenie od modlitwy i od pokory". ${ }^{8}$ Tę czujność

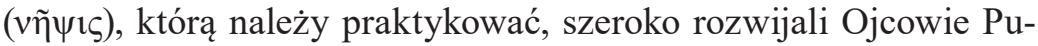
styni. Zachowanie serca dla nieustannej modlitwy i ciągła medytacja Pisma Świętego były uważane za główne i najważniejsze zajęcia ich życia codziennego. I z tego powodu przebywanie w celi nabrało ogromnej wagi, jak pisze Kallistos Ware: „Będąca zewnętrzną oprawą hezychazmu cela jest przede wszystkim warsztatem nieustannej

6 Od tego też pochodzi nazwa „messalianie” po syryjsku, czyli „ludzie modlący się", euchici po grecku; zob. Te o d o r e t z C y r u, Historia ecclesiastica, IV 10.

Wydawca pism Marka Eremity w Sources Chrétiennes, ojciec de Durand,

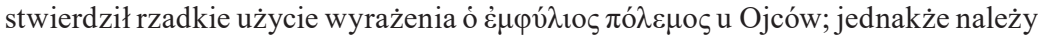
zauważyć, że Jan Chryzostom stosuje go kilka razy.

8 Marek Ere mit a, Disputatio cum quodam causidico, 4, PG 65, 1076. 
modlitwy". ${ }^{9}$ Marek Eremita, a razem z nim współczesny mu Diadoch z Fotyki, a także inni liczni autorzy tej tradycji ascetycznej (Izaak Syryjczyk, Jak Klimak itd.), przenoszą jednakże akcent. O ile dla Ojców Pustyni cela jest sanktuarium, wyjątkowym miejscem spotkania między Bogiem i człowiekiem, to tą celą u naszego autora staje się samo serce człowieka. Duchowość przenosi się coraz bardziej do wnętrza człowieka. Trzeba zauważyć, że Marek Eremita w swoich dziełach nie używa ani razu rzeczownika „cela” ( $\kappa \varepsilon \lambda \lambda i ́ \alpha)$ i całej terminologii, która jest z nim związana. Chociaż inspiruje się głęboko Apoftegmatami Ojców, nie zajmuje się kwestią przebywania w celi, ale akcentuje i rozwija tematykę chronienia serca.

Jak już mówiliśmy, według Marka Eremity serce jest już od momentu chrztu miejscem obecności Trójcy Świętej. Marek nazywa serce „domem Chrystusa” ${ }^{10}$ lub „ukrytą świętynią serca”: „W każdym człowieku królewski rozum czerpie najpierw z ukrytej świątyni serca piękne podpowiedzi Chrystusa, który to serce zamieszkuje". ${ }^{11}$ Marek mówi również o przeniesieniu liturgii ze świątyni i z Kościoła do świątyni ciała i duszy.

Serce jest dla tego teologa nie tylko rzeczywistością fizyczną, ale rzeczywistością duchową. Według Gheorghe’a Ionașcu, u Marka Eremity „serce ucieleśnia integrację i relację: integrację i zjednoczenie całej istoty $\mathrm{z}$ nią samą i jednocześnie z centrum tej istoty znjdującym się w Bogu". ${ }^{12} \mathrm{~W}$ tym kontekście chronienie serca jawi się jako konieczność chronienia obecności Boga w sercu człowieka.

Dla Marka Eremity oddzielenie rozumu (voṽ $)$ od serca jest konsekwencją grzechu, tj. naszej zgody na atak szatana: „kiedy nasz rozum odwraca się od naszego serca (...), daje od razu okazję do ataku

K. W a r e, Le royaume intérieur, Cerf, Paris 1996, s. 83.

10 Marek Eremita, De baptismo, 11, w: Traités I, wstęp i tłum. G. M. D e D u ra n d, Cerf, Paris 1999 (dalej: SCh 445).

11 Tamże, 5; s. 370.

12 Gh. I o n a s c u, The baptismal spirituality of Saint Mark the Ascetic, Summary of the PhDThesis, University of Sibiu, Faculty of Orthodox Theology, Sibiu 2012, s. 28. 
diabła i staje się podatny na złe podszepty". ${ }^{13}$ Jest zatem niezbędne, by zachować rozum i serce zjednoczone w idealnej czujności.

Dla Marka Eremity to rozum jest strażnikiem serca, to on działa, by chronić serce; wszelka walka duchowa odbywa się więc na poziomie rozumu. Rozum jest strażnikiem, który musi czuwać, i to przez modlitwę: „Rozum ma władzę utrzymywania serca w pełnej czujności przez modlitwę, przez dokładanie wysiłku, by wejść do jego nieporuszonych głębi. (...) Ponieważ czyste, najgłębsze izby duszy i dom Chrystusa otrzymują czysty rozum". ${ }^{14}$ Gdy mówi się o modlitwie i wejściu do tych najgłębszych izb, do tych $\tau \alpha \mu \varepsilon \tilde{\alpha} \alpha$, przychodzi na myśl fragment z Mt 6, 6: „Ty zaś, gdy chcesz się modlić, wejdź do swej izdebki, zamknij drzwi i módl się do Ojca twego, który jest

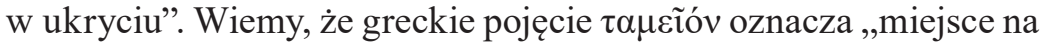
uboczu”, „schowek”, „kryjówkę”. Marek Eremita akcentuje przebywanie w ukryciu, używając przymiotnika w stopniu najwyższym

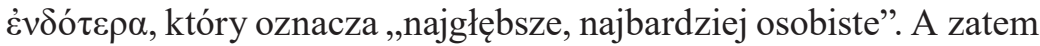
serce jest tym miejscem ukrytym, bardzo głębokim, bardzo osobistym, nad którym rozum ma obowiązek czuwać. Dlaczego? Dalsza część cytatu przynosi wytłumaczenie: dlatego, że tam jest „dom Chrystusa”. Jak zatem dotrzeć do tego „domu Chrystusa”? Jedynie przez modlitwę. Inny fragment z Marka Eremity nam to wyjaśnia: aby „zobaczyć wewnętrzny domu Chrystusa (...), trzeba więc szukać tego domu, stukać do jego drzwi, nie ustając w wysiłkach przez modlitwę". ${ }^{15}$ Modlitwa trafia do najintymnieszej części naszego serca, tam, gdzie przebywa Chrystus.

13 Marek Eremita, De baptismo, 11, s. 366.

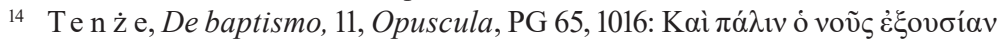

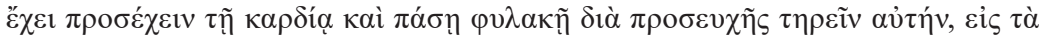

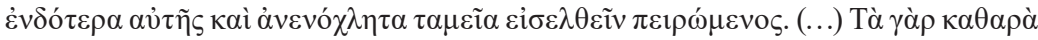

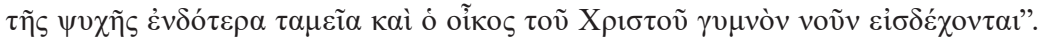
Zob. Prz 4, 23: „Z całą pilnością strzeż swego serca, bo życie ma tam swoje źródło”

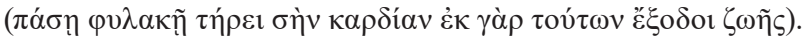

${ }_{15}$ M a rek Eremit a, De his qui putant se ex operibus iustificari, 211, PG

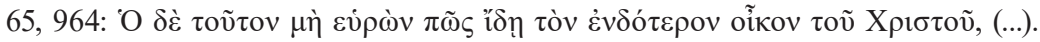


Zatem, według Marka Eremity, w centrum naszego życia duchowego da się wyróżnić dwie aktywności: aspekt ochrony i czujności wobec serca dzięki nieustannej modlitwie i dzięki modlitwie pozbawionej rozproszeń, i jednocześnie aspekt intymności, którą przeżywa się z Bogiem w głębi serca. Zamierzamy teraz zbadać te dwa aspekty.

\section{Modlitwa pozbawiona rozproszeń i modlitwa nieustanna}

Marek kładzie nacisk na wagę modlitwy pozbawionej rozproszeń. Przytacza w tym celu wyrażenie dość typowe dla literatury

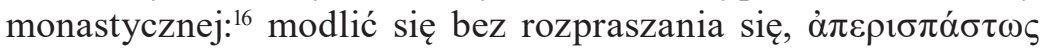
$\pi \rho \sigma_{\varepsilon} \xi_{\alpha} \sigma \theta \alpha 1$. W wszystkich dziełach Marka Eremity ten przysłówek określa modlitwę i teolog czyni z niego warunek spełnienia przez Boga naszych próśb, a przynamniej ich słuchania. „Nie ma idealnej modlitwy bez przyzwania intelektu; jeśli myśl wzywa bez rozpraszania, Pan słucha". ${ }^{17}$

W Rozmowie z prawnikiem Marek odróżnia modlitwę pozbawioną rozproszeń od modlitwy pozornej: „Przez modlitwę rozumiemy nie tyle modlitwę, która wyraża się przez postawę ciała, ale modlitwę, która jest zanoszona do Boga przez myśl pozbawioną rozproszeń". ${ }^{18}$ Kallistos Ware wysuwa hipotezę, że modlitwa nieustanna w wykonaniu messalian była modlitwą mówioną na głos: „Wydaje się, że modlitwa oznaczała dla nich głównie modlitwę na

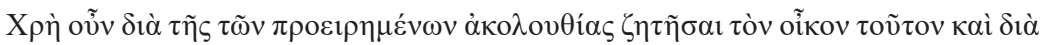

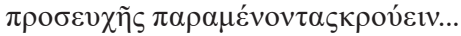

16 Termin ten występuje w 1 Kor 7, 35, ale nie w odniesieniu do modlitwy, lecz służby. W odniesieniu do modlitwy często używa go Ewagriusz z Pontu, jak zaświadcza M. P l e s t e d, The Macarian Legacy: The Place of Macarius-Symeon in the Eastern Christian Tradition, Oxford 2004, s. 105.

${ }_{17}$ Mare k E remit a, De his qui putant se ex operibus iustificari, 31, 936:

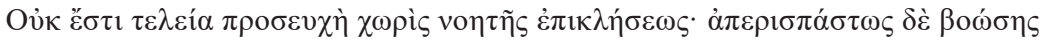

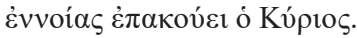

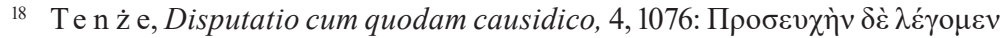

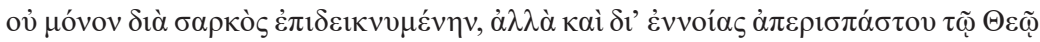
$\varphi \varepsilon \rho о \mu \varepsilon ́ v \eta v$. 
głos. Rozważali modlitwę jako czynność świadomą i dobrowolną, która wyklucza wszelkie inne czynności: modlić się oznacza zatem «mówić modlitwy»". ${ }^{19}$

Tymczasem Marek wyróżnia dwa typy modlitwy i podkreśla to rozróżnienie we wszystkich swoich dziełach: modlitwa ciała, czyli zewnętrzna, i modlitwa wewnętrzna: „Modlitwą chcemy nazywać nie tylko modlitwę, która przejawia się przez ciało, ale również modlitwę, która jest zanoszona Bogu przez medytację pozbawioną rozproszeń

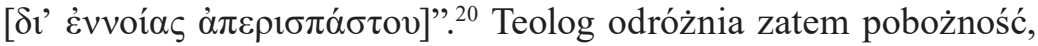
która może być jedynie pozorna, od pobożności wewnętrznej, pobożności serca.

Marek czyni z modlitwy pozbawionej rozproszeń „świętą cnotę”. Posuwa się do utożsamienia jej z zachętą św. Pawła „nieustannie się módlcie” (1Tes 5, 17): „On się naśmiewa z szyderców, a pokornym udziela swej łaski (Prz 3, 34), tej łaski, która nas prowadzi nie tylko do poznania, ale także do posiadania nawyku ( $\check{\xi} \xi \varsigma)$ świętej cnoty, czyli modlitwy pozbawionej rozproszeń, modlitwy, której błogosławiony Paweł, wzywając: «nieustannie się módlcie», każe nam nie zaniedbywać". ${ }^{21}$ Należy zatrzymać się na chwilę na tym cytacie. Modliwa nieustanna i modlitwa pozbawiona rozproszeń są dwoma różnymi rzeczami. Marek Eremita interpretuje jednakże „modlitwę nieustanną" św. Pawła jako modlitwę pozbawioną rozproszeń. W ten sposób zajmuje on pozycję wobec messalian i przenosi akcent: to, co jest ważne dla Marka Eremity, to nie ilość modlitwy ani jej zewnętrzne oznaki, ale skupienie serca w modlitwie. A w celu rozwinięcia swojej myśli, aby opisać modlitwę pozbawioną rozproszeń,

19 K. W a r e, Pray Without Ceasing: The Ideal of Continual Prayer in Eastern Monasticism, Eastern Chruches Review 2(1969) nr 3, s. 253.

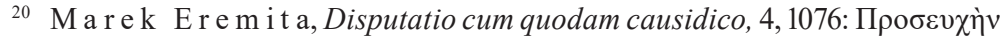

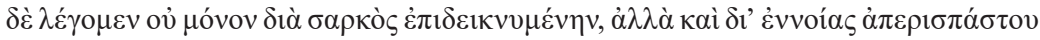
$\tau \tilde{\omega} \Theta \varepsilon \tilde{\omega} \varphi \varepsilon \rho \circ \mu \varepsilon \dot{\varepsilon} \eta v$.

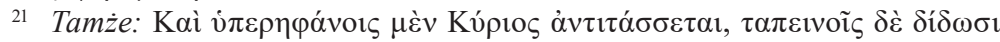

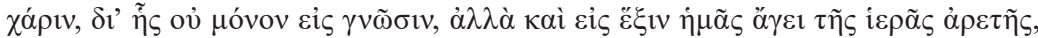

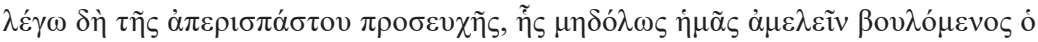

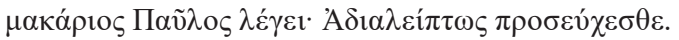


nie waha się sięgnąć po słownictwo przwie nieużywane używane przez Ojców.

Stosuje, oczywiście, pojęcia już wprowadzone przez innych, jak

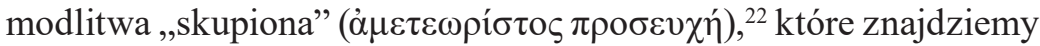
już u Ewagriusza z Pontu, ale również u Bazylego Wielkiego i innych. Lecz Marek Eremita używa także terminu zaskakującego, po który oprócz niego sięga tylko Nil z Ancyry, ${ }^{23}$ a chodzi o przymiotnik á $\rho \varepsilon \mu \beta$ s, którego pierwsze zastosowanie służy do określenia mod-

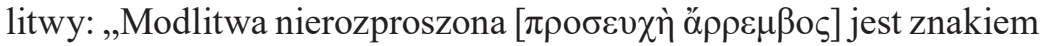
miłości do Boga od tego, kto w niej trwa". ${ }^{24}$ A drugie użycie określa stan myśli w modlitwie: „Odkrywamy w ten sposób, że istnieje modlitwa i modlitwa. Inną rzeczą jest wzywać Boga myślą nierozproszoną, a inną być obecnym ciałem z myślą rozproszoną". ${ }^{25} \mathrm{Jak}$ zaznacza Marcus Plested, „pojęcia $\dot{\varepsilon} \mu \beta \alpha \sigma \mu o ́ \varsigma$ (błądzenie) i $\rho \varepsilon ́ \mu \beta o \mu \alpha 1$ (błądzić) są standardem u Makarego Wielkiego Egipskiego ${ }^{26}$ i służą zaznaczeniu błądzenia myśli w rozumie". ${ }^{27}$ Wiemy dzięki badaniom znawców, jak O. Hesse ${ }^{28}$ i M. Plested, ${ }^{29}$ że Marek Eremita pisze swoje

22 Zob. tamże, 1084.

23 U Nila z Ancyry znajdujemy również ten przymiotnik opisujący modlitwę:

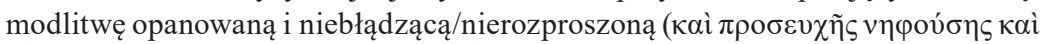
$\dot{\alpha} \rho \varepsilon ́ \mu \beta o v)$.

${ }_{24}$ Mare k E r e m it a, De his qui putant se ex operibus iustificari, 90, 944:

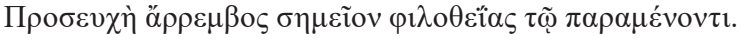

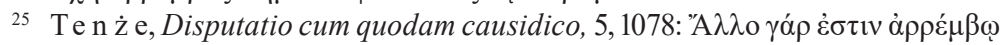

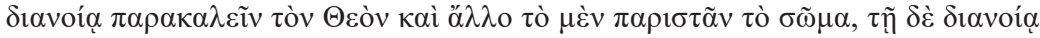
$\dot{\rho} \varepsilon \beta \beta \varepsilon \sigma \theta \alpha 1$.

26 Na przykład w Homilii 29, 1, coll. B, Makary pisze: „i oby dusza daleka była od świata materialnego i od błądzenia myśli tak, aby wzrosła w modlitwie

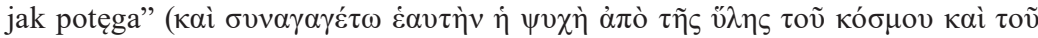

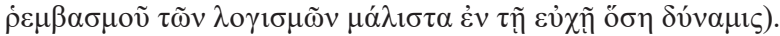

27 Zob. M. P l e s t e d, The Macarian Legacy: The Place of Macarius-Symeon in the Eastern Christian Tradition, s. 105.

28 Zob. O. H e s s e, Markus Eremita, Asketische und Dogmatische Schriften, Stuttgart 1985, s. 123.

${ }_{29}$ Zob. M. P l e s t e d, The Macarian Legacy: The Place of Macarius-Symeon in the Eastern Christian Tradition s. 105. 
dzieła, mając za podstawę teksty tradycji makariańskiej (Makarego Wielkiego Egipskiego i Pseudo-Makarego Symeona Egipskiego). Inspiruje się więc tutaj pojęciem znalezionym w tej tradycji, odwracając jego znaczenie tak, aby stworzyć wyrażenie określające modlitwę „nie-błądzącą” w polu myśli, modlitwę zatem skierowaną ku Bogu ( $\pi \alpha \rho \alpha \kappa \alpha \lambda \varepsilon \tilde{i} v \tau$ tòv $\Theta \varepsilon o ̀ v)$.

Wydaje się, że Marek Eremita lubi stosować w tematyce modlitwy określenia nieużywane przez poprzedników. Jeszcze inne pojęcie, obecne jedyne w jego dziełach, jest warte odnotowania. Marek wzywa bowiem do modlitwy „w pełnej koncentracji”. ${ }^{30}$ Przy-

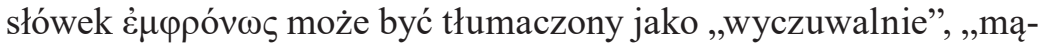
drze" lub „świadomie” i we wszystkich przypadkach wskazuje na uwagę, na poznanie i kontrolę wnętrza. Przymiotnik pochodzący od tego przysłówka może wskazywać tego, kto ma świadomość siebie (w odróżnieniu od kogoś, kto byłby uśpiony lub martwy), kogoś posiadającego władze umysłowe, umiejętności logicznego myślenia i analizowania. Marek Eremita jest jedynym greckim autorem patrystycznym używającym tego pojęcia do opisania modlitwy:

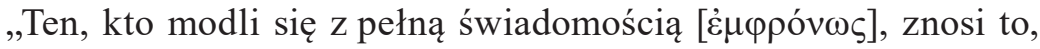
co mu się zdarza; ale ten, który pamięta zło, nie modlił się jeszcze

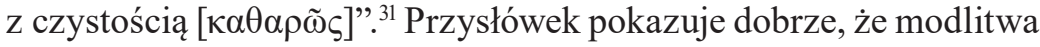
zakłada wewnętrzną uwagę, uświadomienie sobie tego, co się dzieje na poziomie rozumu.

W innym tekście obserwujemy użycie czasownika (,uzbroić się") bardzo znaczącego w teologii Marka Eremity. W Rozmowie z prawnikiem traktuje on modlitwę jako priorytet życia chrześcijańskiego: „Inną sprawą jest przestrzegać ustalonych pór i modlić

30 Cudzysłów jest używany tutaj po to, by odróżnić modlitwę proponowaną przez Marka Eremitę od współczesnej techniki medytacyjnej inspirującej się prądami wschodnimi, które różnią się, według nas, od tego, czego mogą nauczać Ojcowie. Dla nich bowiem jedynym celem medytacji jest Bóg, a nie obecność w teraźniejszości. U Marka Eremity cel jest bardzo chrystocentryczny.

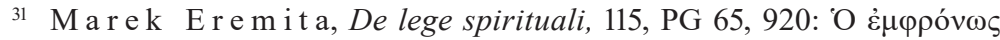

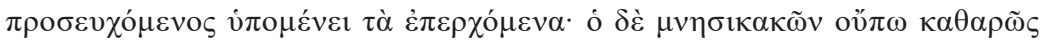
$\pi \rho \circ\rceil \eta \dot{\xi} \alpha \tau$. 
się niespiesznie po wypełnieniu swoich obowiązków społecznych, a inną wybierać, gdy tylko to możliwe, modlitwę i uzbroić się w niąą2

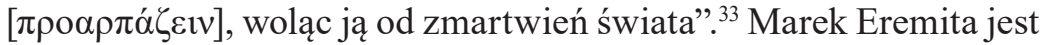
jedynym autorem greckim, który używa odnośnie do modlitwy tego czasownika nie używanego w tekście Biblii. Ma on oznaczać całą aktywność człowieka, mającą na celu podjęcie modlitwy wcześniej tak, aby się w nią niejako uzbroić przed działaniem szatana, który chce oddalić człowieka od Boga przez zajmowanie go sprawami ziemskimi. Aspekt aktywności człowieka, aspekt uczestnictwa jest również rozbudowany w idei, w ramach której modlitwa jest pracą, dodajmy nieustanną, ,ponieważ diabeł nie przestaje toczyć z nami wojny”: ${ }^{34}$ „Praca dla początkujących, dla mających pewną wprawę, jak i dla biegłych, modlitwa, to oczyszczenie myśli i cierpliwość wobec wydarzeń". ${ }^{35}$ Nie ma więc różnicy w etapach życia duchowego, jeśli chodzi o modlitwę: jest ona niezbędna dla każdego.

Według Marka Eremity nie należy zatem podejmować niczego

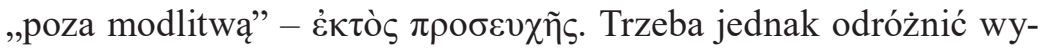
rażenie ,poza modlitwą”, chociaż niuans znaczenia nie jest duży,

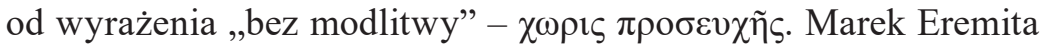
używa często za licznymi Ojcami tego drugiego określenia, które stanowi część jego słownictwa, ale czyni powyższe rozróżnienie: można być poza modlitwą, na zewnątrz niej. Ten przyimek jest używany generalnie przez Ojców w kontekście Trójcy lub w kontekście chrystologicznym, aby stwierdzić, że Syn i Duch nie są poza Ojcem lub że Chrystus nie jest poza stworzeniem lub poza ciałem.

32 Nie powielamy tutaj tłumaczenia z Sources Chrétiennes s'y agripper (,„chwycić się kurczowo”), ale i tłumaczenie Bellefontaine’a libérés d'avance (,z góry wyzwoleni”) nie wydaje się nam poprawne. Modlitwę wyraża tu biernik czasownika przechodniego $\pi \rho \circ \alpha \rho \pi \alpha ́ \zeta \omega$ (przyp. autorki). W polskim tłumaczeniu wydawało się lepsze przełożyć użyty przez autorkę czasownik s'emparer (,zawładnąć”, ,pobić”) na „uzbroić się” (przyp. tłum.).

33 Marek Erem it a, Disputatio cum quodam causidico, 5, 1077.

34 Te n ż e, De paenitentia, 11.

35 Tamże. 
Marek Eremita decyduje się na stosowanie tego przyimka w kontekście modlitwy i wyrażenie ,poza modlitwą” wraca we wszystkich jego dziełach. By nie przedłużać tego wątku, zacytujemy tylko jedno

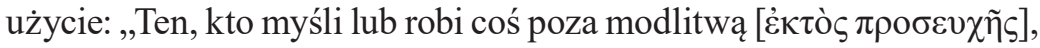
nie podejmuje dobrej drogi, by osiągnąć swój cel". ${ }^{36}$ Widać tutaj ponownie, że Marek Eremita daje dowód oryginalności i kreatywności w swoim słownictwie dotyczącym modlitwy. Używając zwrotu bardzo mało stosowanego przez Ojców odnośnie do modlitwy, ale tradycyjnie używanego w kontekście perychorezy trynitarnej lub w rozważaniach teologicznych o wcieleniu, daje dyskretnie do zrozumienia, że modlitwa powinna przylgnąć do ludzkigo serca tak, jak Trójca stanowi jedno w swojej relacji wewnątrzboskiej, lub tak, jak dwie natury Chrystusa są zjednoczone w jednej osobie.

Czujność jest zatem strażniczką modlitwy: dzięki niej wszystko, co stanowi przeszkodę dla modlitwy, jest wyeliminowane, w tym i podszepty szatana, który stara się przeniknąć do ludzkiego serca. Dzięki czujności i chronieniu serca modlitwa staje się modlitwą nieustanną. „Wzmacnia się ona i pogłębia, włada całym człowiekiem i koncentruje w sobie znaczną energię, całkowicie skierowaną w stronę Boga jako Osoby, w stronę spotkania, komunikacji i zjednoczenia z Chrystusem. W finale wysiłku modlitewnego, w którym człowiek otwiera się całkowicie na spotanie z Bogiem, błagalne wezwanie staje się prawdziwym spotkaniem między energią ludzką i Boską". ${ }^{37}$

36 Te n ż e, De his qui putant se ex operibus iustificari, 154.

37 Zob. S. H o r u j y, L'anthropologie synergique: vers une nouvelle conception de l'homme, Revue philosophique de la France et de l'étranger 39(2014) nr 3, s. 363-375. 


\section{Bliskość z Bogiem w modlitwie: terminologia miłości}

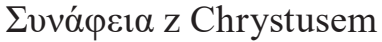

„Mówi się, że modlitwa stanowi jedną z cnót i jest jednocześnie ich matką, bowiem rodzą się one z niej dzięki jedności z Chrystusem". ${ }^{38}$ Dla Marka Eremity modlitwa człowieka i Chrystus łączą się ze sobą, by zrodzić cnoty! Znajduje się tutaj ważne do odnotowania słownictwo związane ze ślubem i małżeństwem. Pierwszym jest czasownik

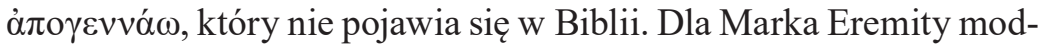
litwa to zjednoczenie się w Chrystusie obfitujące w skutki, ponieważ rodzi ono wszelkie inne cnoty. Przez wybór czasownika otrzymujemy tutaj wspaniałą ilustrację synergii między Bogiem a człowiekiem: cnoty pochodzą ze zjednoczenia Chrystusa z modlitwą człowieka...

Przejdźmy teraz do drugiego pojęcia, tj. do zjednoczenia бvvópeı filozoficznym ,spójność”. Rzeczownik ten oznacza z kolei zjednoczenie między dwoma całościami i pochodzi od czasownika ovvó $\pi \tau \omega$ : „wiązać razem”, „łączyć dwa elementy jeden z drugim”. Znajduje się go często u Grzegorza z Nyssy, a także u Bazylego Wielkiego, którzy za jego pomocą określają zwłaszcza zjednoczenie mogące istnieć między Ojcem i Synem. ${ }^{39}$

Pojęcie jest też nierzadko stosowane przez Jana Chryzostoma, który używa go często w perspektywie małżeńskiej, np. w Katechezach chrzcielnych. Komentując słowa Chrystusa, „A tak już nie są dwoje, lecz jedno ciało”, pisze on: „Tak wielka staje się jedność

38 Marek Eremit a, De his qui putant se ex operibus iustificari, 33, 936:

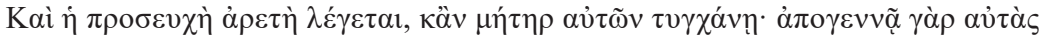

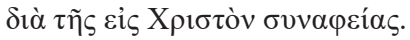

39 Zob. Gr zegor z z Ny s s y, Contre Eunome, III 6, 18 w: W. J a e g e r (red.),

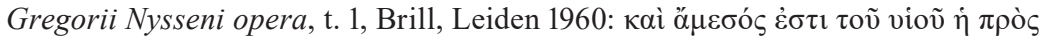

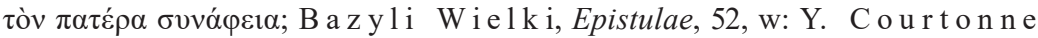

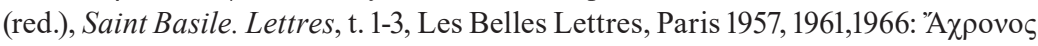

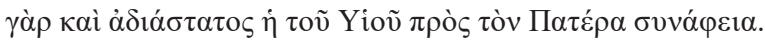


i zjednoczenie, że dwoje staje się jednym ciałem". ${ }^{40} \mathrm{~W}$ tradycji makariańskiej ${ }^{41}$ to wyrażenie jest używane, by opisać zjednoczenie ducha w jego obecym stanie z Panem czy z Bogiem, ale nie jest zarezerwowane dla modlitwy. Grzegorz z Nyssy wydaje się również potencjalnym źródłem inspiracji Marka Eremity do idei mistycznej unii z Chrystusem. Jednak żaden autor poprzedzający Marka nie używa nigdy tego pojęcia do opisania zjednoczenia modlitwy człowieka z Chrystusem tak, jak robi to Marek, a to dlatego, że najczęściej stosowany jest przez Ojców inny termin, topos: $\sigma u ́ v \alpha \xi 1 \varsigma$ - „zjednoczenie z Bogiem". Z kolei w dziełach Marka Eremity to pojęcie nie pojawia się ani razu! Wybiera on бvvó $\varphi \varepsilon ı \alpha$, wyrażenie o konotacji bardziej „miłosnej”, a będąc wierny chrystocentryzmowi, decyduje się podkreślić zjednoczenie z Chrystusem.

Zatem modlitwa pozwala na intymną relację z Chrystusem bliskim w modlitwie, z Chrystusem postrzeganym przede wszystkim jako lekarz: ilustruje to inne bardzo piękne zdanie Marka Eremity: „Nie wstawaj, jeśli ronisz łzy w czasie modlitwy, ponieważ to Chrystus dotknął twoich oczu po to, żebyś odnalazł wzrok rozumu". ${ }^{42}$

$40 \mathrm{~J}$ a n Chry zos to m, Catecheses ad illuminandos, I 13, w: Ad illuminandos

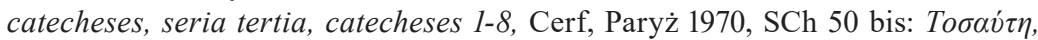

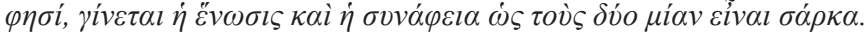

${ }_{41}$ Zob. P s e u d o - M a k a r y / S y m e o n, Sermo 4, 1 (Sermones 64, coll. B); Homilia 40 (Homiliae spirituales 50, coll. H) itd., w: Homiliae spirituales 50: Die 50 geistlichen homilien des Makarios, Walter de Gruyter \& Co, Berlin 1964.

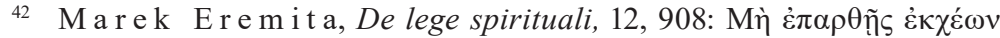

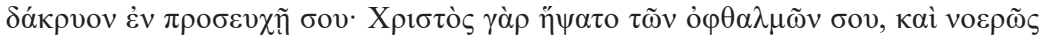
$\alpha \dot{\alpha} \varepsilon \dot{\beta} \lambda \varepsilon \psi \alpha \varsigma$. To wspaniałe zdanie przyciągnie uwagę Grzegorza Palamasa w jego traktacie Pro hesychastis, II 2, 7, gdzie autor trochę je zmodyfikuje: ,jeśli płacz się przedłuża podczas twojej modlitwy, to Bóg dotknął oczu twojego serca, abyś

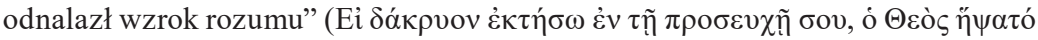

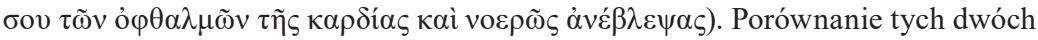
cytatów jest okazją do pokazania jeszcze raz chrystocentrycznego wymiaru dzieła Marka Eremity. Palamas mówi o Bogu, który dotyka oczu, zaś dla Marka Eremity jest nim Chrystus. We wszystkich swoich dziełach umieszcza on Chrystusa w centrum. 


\section{Zjednoczenie z Bogiem przez modlitwę}

Nasz autor wskazuje na duchową perspektywę: ,ppołączyć się z Bo-

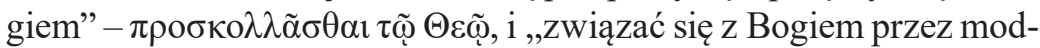

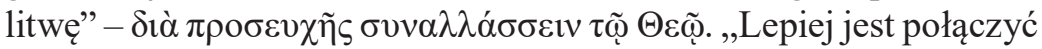
się z Bogiem [ $\pi \rho 0 \sigma \kappa o \lambda \lambda \tilde{\alpha} \sigma \theta \alpha \iota \tau \tilde{\omega} \Theta \varepsilon \tilde{\omega}]$ przez modlitwę i nadzieję niż myśleć o rzeczach zewnętrznych, jakkolwiek byłyby one przydatne". ${ }^{43}$ „Jeśli więc chcesz być zbawiony i osiągnąć poznanie prawdy, zmuś się codziennie do przekroczenia granicy wrażliwości i, przez samą tylko nadzieję, do połączenia się z Bogiem. Kiedy bowiem jesteś wbrew sobie odwrócony od Boga, napotkasz siły, rzeczy, które cię zdominują i pokonają swoimi podszeptami, ale przez modlitwę zwyciężysz". ${ }^{44}$ Czasownik $\pi \rho \circ \sigma \kappa o \lambda \lambda \tilde{\alpha} \sigma \theta \alpha$ oznacza „złączyć się, by stanowić jedność". W Piśmie Świętym odnajdujemy go w Rdz 2, 24, Mt 19, 5 / Mk 10, 7, Ef 5, 31. W Księdze Powtórzonego Prawa i w Ps 73 (72), 28 odnajdujemy określenie „złączyć się z Bogiem”. 45

John Chryssavgis, mówiąc o Janie Klimaku używającym tego wyrażenia, nie waha się mówić o „terminologii erotycznej”, tłumacząc, że zabarwienie seksualne jest w grece oczywiste. ${ }^{46}$ Zamiast wskazywać na charakter seksualny, wolimy powiedzieć, że jeśli Marek Eremita używa tego czasownika, to ma na celu pokazanie czytelnikowi znającemu grekę wymiar ślubny, intymny, miłosny, wierzący jest wzywany, by przeżyć go z Bogiem przez modlitwę. Inni Ojcowie nie używają często tego określenia w odniesieniu do

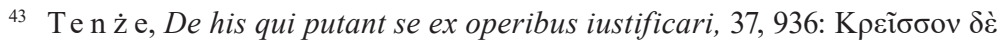

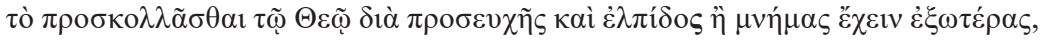

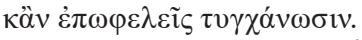

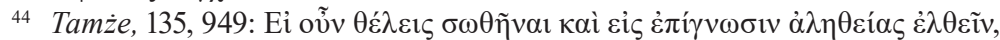

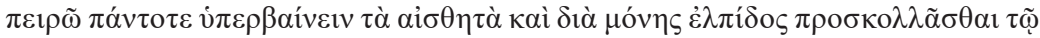

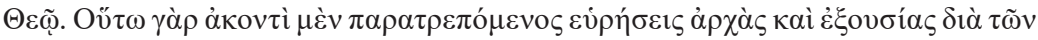

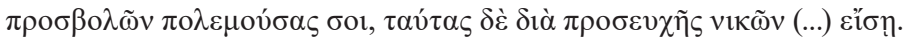

${ }^{45}$ W Biblii Tysiąclecia znajdujemy odpowiednio wyrażenia „trzymać się Boga” i „być blisko Boga” - przyp. tłum.

46 Zob. J. C h r y s s a vg i s, John Climacus: From the Egyptian Desert to the Sinaite Mountain, Hants 2004, s. 206. 
modlitwy i chociaż często komentują werset Psalmu 72, to wspomnienie o połączeniu się z Bogiem przez modlitwę występuje u nich bardzo rzadko.

I znowu obserwujemy, że Marek Eremita używa zaskakującego wyrażenia: „Kto chce się zamknąć na wszelkie zachęty do czynienia

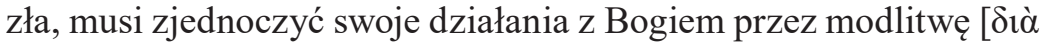

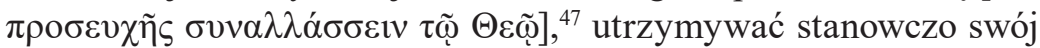
rozum $\mathrm{w}$ pokładaniu w Nim nadziei, i nic sobie nie robić, na tyle, na ile jest to możliwe, z trosk materialnych". ${ }^{48}$ Słowniki (Bailly, Lampe, LSJM) ${ }^{49}$ tłumaczą ten czasownik jako „umieścić w relacji” (z celownikiem, jak w cytacie Marka Eremity), „złączyć się przez relację seksualną", „wejść w umowę małżeńską".

Inni autorzy chrześcijańscy nie łączą tego czasownika z Bogiem, co zwraca naszą uwagę. ${ }^{50}$ Marek Eremita używa go, by opisać relacje między człowiekiem i Bogiem. Używa też tego czasownika jeszcze raz w tym samym traktacie, łącząc go z Bogiem i mówiąc o tych, którzy nie łączą swojej woli z Bogiem i znajdują się zatem w pułapce własnych zajęć oraz zostają zdominowani przez swoich wrogów. ${ }^{51}$

47 W Sources Chrétiennes ojciec de Durand wybiera tłumaczenie: „musi, przez modlitwę, podjąć zobowiązanie wobec Boga".

${ }_{48}$ Mare k Eremit a, De his qui putant se ex operibus iustificari, 160,

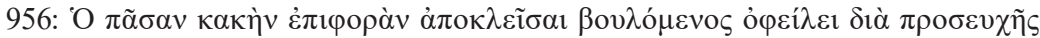

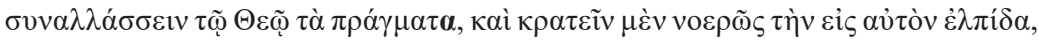

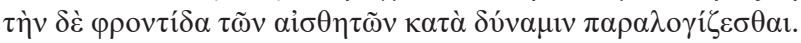

49 Mowa o słownikach A. Bailly'ego, Dictionnaire grec-français, G. Lampego, A Patristic Greek Lexicon, i H. Liddella, R. Scotta, A Greek-English Lexiconprzyp. tłum.

50 W Piśmie Świętym to czasownik hapax legomenon pojawiający się w Dz 7, 26:

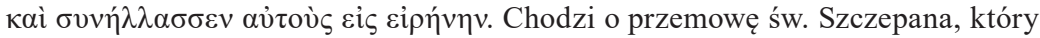
przywołuje postać Mojżesza rozmawiającego z dwoma skłóconymi braćmi i „łączącego" ich, by zawarli pokój. Często stosuje się ten czasownik w literaturze greckiej, aby opisać pogodzenie się dwóch osób. W Biblii Tysiąclecia w Dz 7, 26 nie znajdujemy czasownika „łączyć”, lecz „pogodzić” (przyp. tłum.).

${ }^{51}$ Zob. M a r e k E r e m it a, De his qui putant se ex operibus iustificari, 149,

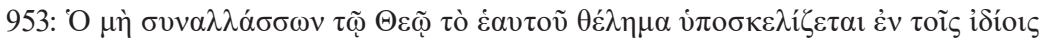

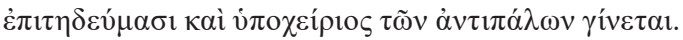


Tym samym Marek Eremita podkreśla jeszcze raz zaangażowanie o charakterze „małżeńskim”: zjednoczenie modlitwy i woli.

\section{Kochać Boga przez modlitwę}

Wróćmy do przywołanego wcześniej cytatu: „Modlitwa niebłą-

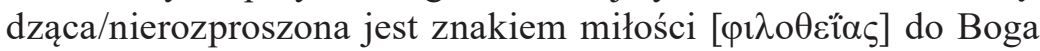
od tego, kto w niej trwa". ${ }^{52}$ Analizowaliśmy już wcześniej modlitwę „niebłądzącą”, specyficzną dla Marka Eremity, ale teraz naszą uwage przyciąga pojęcie $\varphi \imath \lambda \circ \theta \varepsilon \Uparrow \alpha$, a to dlatego, że jest pełne znaczeń i ponownie względnie rzadko używane przez autorów chrześcijań-

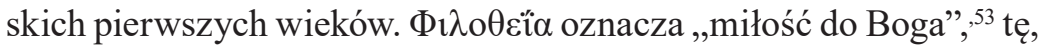
którą człowiek może okazać. Należy odróżnić pojęcie $\varphi \imath \lambda \mathrm{o} \theta \varepsilon i \hat{i} \alpha$ od $\theta \varepsilon \circ \varphi \imath \lambda i ́ \alpha$, nawet jeśli drugie z tych określeń mogło ewoluować w literaturze antycznej i wskazywać również osobę, która daje dowód miłości do Boga. ${ }^{54}$ We wszystkich przypadkach $\varphi \imath \lambda o \theta \varepsilon i \alpha$ opisuje jasno miłość, którą człowiek może okazać Bogu.

Pojęcie to znajduje się np. w Apoftegmatach: „Przeszła na nich sama kontemplacja za sprawą Boga, dzięki ich wielkiej skrusze

52 Tamże, 90.

53 Należy zauważyć, że słownik Bailly’ego nie podaje definicji tego słowa. Powyższa definicja pochodzi ze słownika Liddella/Scotta i jest potwierdzona przez Lampego.

${ }_{54}$ M.-F. Hazebroucq ustala ewolucję językową pojęć $\theta \varepsilon o \varphi \imath \lambda i ́ \alpha$ i $\varphi \imath \lambda o \theta \varepsilon i \hbar \alpha$

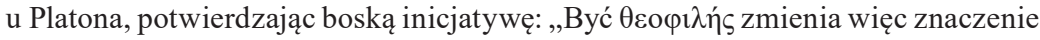
pod wpływem Platona i wydaje się przechodzić ze znaczenia biernego, oznaczającego osobę, która cieszy się przychylnością bogów za sprawą swoich zasług, do znaczenia czynnego, oznaczającego osobę, która kocha to, co boskie, by znaczyć ostatecznie wysiłek czysto filozoficzny mający na celu upodobnić się do bogów na tyle, na ile jest to możliwe dla śmiertelnika. Nie ma większego szczęścia, znaku

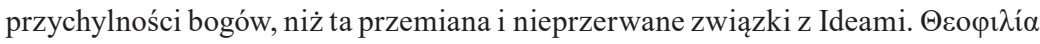

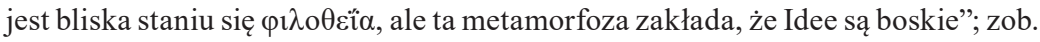
M.-F. H a z e b r o u c q, Philosophie, Bulletin de Liaison CRDP 16/1997-1998, s. 15. Widzimy więc wyraźnie, że od czasów antycznych $\varphi \imath \lambda o \theta \varepsilon i \hat{\alpha} \alpha$ jest pochodzenia czysto boskiego. 
i miłości Bożej". ${ }^{55}$ Marek Eremita używa pojęcia $\varphi ı \lambda o \theta \varepsilon i ̋ \alpha$ tylko raz w traktacie $O$ chrzcie, w którym mówi w sposób dość zaskakujący: „Zła myśl jest znakiem miłości do Boga tych ludzi, którzy ją w sobie niszczą, nie jest zaś grzechem". ${ }^{56}$ Marek Eremita rozwija ten wątek, mówiąc, że samo pojawienie się myśli nie jest grzechem, że jest nim swobodna rozmowa, którą człowiek może z taką myślą mieć i że niesłuchanie podszeptów, niezgodzenie się na nie, jest znakiem miłości do Boga.

W tych dwóch cytatach człowiek pokazany jest więc jako mający władzę, by dać swoją miłość Bogu przez modlitwę bez rozproszeń, ale również przez walkę i odrzucenie złych myśli, chcących przeniknąć do jego serca. Miłość człowieka jest zatem ,aktywna” w tym dwuelementowym działaniu, którego części są tak naprawdę jednym i tym samym: czujnością, by osiągnąć modlitwę bez rozproszeń, możliwą dlatego, że złe myśli zostały już przegonione. Dzięki temu człowiek modlący się może być całkowicie skoncentrowany na Bogu. Marek Eremita podkreśla fakt, że wysiłek człowieka stanowi jedynie owoc jego miłości do Boga, a nie środek do osiągnięcia czegoś.

Marek Eremita stawia czoło massalianom, którzy używają modlitwy ciągłej jako sposobu osiągnięcia zbawienia, który ma skutkować przyjściem Ducha Świętego. Messalianie „instrumentalizują” w ten sposób modlitwę. Studia nad dziełami teologa, a zwłaszcza nad słownictwem wybranym do opisywania modlitwy, pokazują wyraźnie zajętą przez niego pozycję całkowicie różną od podejścia messalian. Modlitwa nie jest dla Marka Eremity środkiem, instrumentem: jest

55 M. S t a row i e y s k i (tłum.), Apoftegmaty Ojców Pustyni. Jak należy przebywać w celi i o kontemplacji, s. 9, J.-C. G u y (red.), Un entretien monastique sur la contemplation, Revue de recherche de sciences religieuses 50/1962, s. 233 :

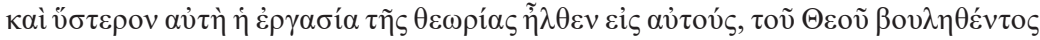

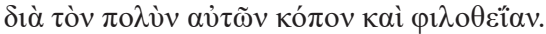

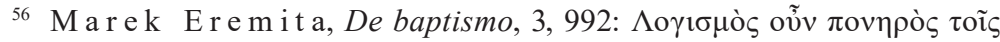

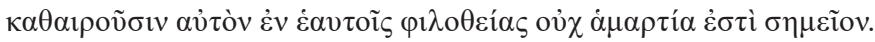


ona znakiem miłości, wymianą miłości intymnej z Bogiem. Sięgając po terminologię ślubną, przesuwa on wyraźnie akcent; modlitwa staje się miejscem miłości, którą przeżywa się w sercu.

Émilie ESCURE-DELPEUCH

(z francuskiego ttum. Agnieszka Maciejek)

Słowa kluczowe: Marek Eremita; modlitwa

Keywords: Mark the Ascetic; prayer

\section{Prayer according to Mark the Ascetic}

\section{Summary}

Mark the Ascetic is opposed to the Messalians. According to them, Satan inhabits the human heart from the fall and must be removed through constant prayer and expelled by receiving the Holy Spirit. For Mark the Ascetic it is the Holy Spirit who lives in the human heart from his baptism. The believer must be vigilant because Satan wants to come from outside to take the place of the Spirit. The continuous prayer is therefore not a way of getting closer to God. It is a weapon in a spiritual battle trying to distance us from God. It is even more than a weapon: it is love, because God and man are from the baptism in a love relationship which is expressed by prayer. Mark the Ascetic confronts the Messalians, who use the continuous prayer as a way of achieving salvation, a way which should result in the coming of the Holy Spirit. In this way, the Messalians "instrumentalise" prayer. The studies on Mark's works, especially on his vocabulary to describe prayer, show his clearly defined position, which is completely different from the approach of the Messalians. Prayer for Mark the Ascetic is neither means, nor instrument. It is a sign of love, an exchange of intimate love with God. By reaching for wedding terminology, Mark clearly shifts the accenton love with God. Prayer becomes a place of love that is experienced in the heart of the faithful. 